\title{
Obesity and Related Disorders: An International Perspective
}

\author{
Mohammed H Moghadasian ${ }^{1,2 *}$, Luc Clair ${ }^{2,3}$, Francesca Bonomini ${ }^{4}$, Gaia Favero ${ }^{4}$ and Rita Rezzani ${ }^{4}$ \\ ${ }^{1}$ Department of Food \& Human Nutritional Sciences, University of Manitoba, Canada \\ ${ }^{2}$ Canadian Centre for Agri-Food Research in Health and Medicine, St. Boniface Hospital Research Centre, Canada \\ ${ }^{3}$ Department of Economics, University of Winnipeg, Canada \\ ${ }^{4}$ Anatomy and Physiopathology Division, Department of Clinical and Experimental Sciences, University of Brescia, Italy
}

Submission: February 08, 2018; Published: July 13, 2018

*Corresponding author: Mohammed Moghadasian, Department of Food \& Human Nutritional Sciences, University of Manitoba, Canadian Centre for Agri-Food Research in Health and Medicine, 351 Tache Avenue, Winnipeg, Manitoba, Canada, Tel: 1-204-235-3934; Fax: 1-204-237-4018;

Email: mmoghadasian@sbrc.ca

\section{Abstract}

In this short communication, attempts have been made to summarize information on the international status of obesity and related disorders. Briefly, contributing risk factors have been discussed, and preventive strategies have been suggested.

Keywords: Obesity; Diabetes; Cardiovascular disease; Diets; Lifestyle; Physical activity; International

\section{Introduction}

\section{International obesity status}

Obesity, as defined by having a BMI of $>30$, is becoming one of the most problematic health issues worldwide, affecting both children and adults. Many chronic diseases are closely linked with obesity [1-3]. Metabolic disorders including dyslipidemia and insulin resistance and/or diabetes are frequently seen in obese patients. Metabolic syndrome is defined as a combination of abnormal lipid and glucose metabolism plus hypertension which is developed in overweight (individuals with a BMI of $>25$ and $<30$ ) or obese subjects $[4,5]$. Current statistics indicate that the prevalence of obesity and overweight is ever increasing in both developed and developing countries. However, such statistical data cannot define a strong association between the overall state of the country and the percentage of obese individuals among the residence of that country. For example, prevalence of obesity among adults in Japan is reported to be $3.3 \%$ and in Ethiopia $4.0 \%$, while it is reported to be $33.0 \%$ in the Unites State of America or $28.0 \%$ in Canada [5]. Table 1 summarizes the rates of obesity among countries with different political, economical, educational and natural resources features [6-17]. These statistics can raise the question of what factors contribute to the current most troubling world health dilemma.

Like many other metabolic disorders, one may consider modifiable and non-modifiable risk factors for obesity and overweight problems. One of the modifiable risk factor is calorie intake. It is known that body weight is a result of excess energy intake and/or reduced energy expenditure. At least in part, the excess amounts of energy can be deposited in the body in the form of fat, resulting in a state of overweight or obesity. Many human studies have reported that pathological excess amounts of fat are associated with a number of other abnormalities including dyslipidemia, atherosclerosis, hypertension, stroke, some types of cancers, diabetes, and others [4,5]. Our knowledge of how excess amounts of body fat can cause or mediate such other metabolic abnormalities is very limited; however, an imbalance in inflammatory pathways and oxidative stress can play a crucial role $[4,5]$.

Figure 1 demonstrates that among many nations the rate of obesity is considerably different. As evident, obesity rate in Japan has increased very minimally over four-decades (approximately 1975 to 2015). On the other hand, this rate was significantly increased in the United States of America (USA) and Australia over the same period of time. One may think that diversity and multicultural background may be more profound in the USA or Australia as compared to that in Japan. Another speculation may be related to dietary habits and lifestyle particularly the use of fast foods and/or restaurant foods.

A relatively large increase in obesity rate from 1980 to 2010 seen in the USA population (Figure 1) may be attributed to purchase power and food pricing [18]. It is reported that in 


\section{Current Research in Diabetes \& Obesity Journal}

the 1980s, food prices rose slower than inflation. This means that food was cheaper relative to other goods. Furthermore, the price of junk-food rose slower than the price of healthy/ nutritious foods, causing a shift towards consuming more junk- foods $[9,19,20]$. Secondly, technological advancements in food preparation (including advanced food processing) meant lower money and time costs devoted to eating, increasing the calorie intake among general population [9,21-23].

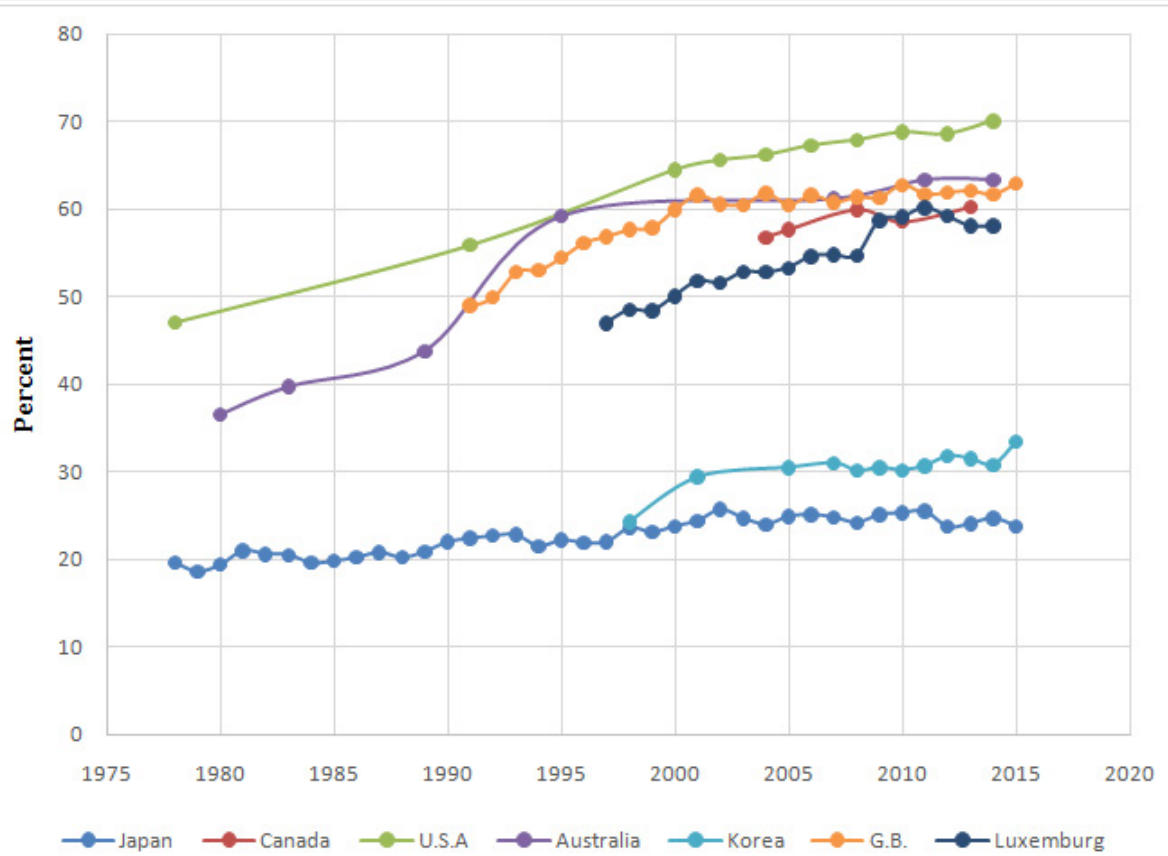

Figure 1: Obesity rates for individuals 15 years or older for selected OECD countries.

\section{Obesity paradox}

It has been suggested that high calorie intake and/or low energy expenditure can lead to overweight and obesity [21]. This notion can be argued in several perspectives. Firstly, it has been now decades that health authorities from many countries and organizations recommending reductions in fat calorie intake to be less than $30 \%$ of total energy intake, predominantly to reduce cardiovascular risk factors for primary prevention purposes [22]. Attempts have been made by advocators to educate general population at least in developed countries to achieve such milestones in fat intakes. Fat is an energy rich nutrient and can be widely varied in quality for human consumption. Generally, high intakes of saturated fat and industry-produced trans fat are considered to increase cardiovascular risk factors. On the other hand, mono-unsaturated and poly-unsaturated fatty acids, particularly long-chain omega 3 fatty acids are suggested to be cardiovascular friendly [23]. Thus, Western countries started to ban or limit industry-produced trans fat in food chain, and at the same time encourage production, marketing and consumption of foods rich in long-chain polyunsaturated fats in an attempt to reduce the ratio of dietary omega- 6 to omega-3 fat intake to 2-4:1 for promoting quality of life. Current literature clearly shows effectiveness of such modifications in dietary behavior, at least in part, in segments of populations in the West. However, such dietary modifications have been associated with a paradoxical increase in overweight and obesity not only in adults but also in children [23].

Another unexplained observation is the lack of association between obesity rate and the overall status of the country in regard to literacy, income, food security and other relevant features. One may think that increased literacy may lead to a better decision making for diets, lifestyle and health. Similarly, a link between education, income, food security, and lifestyle has been established by many community-based human trials. However, Table 1 demonstrates disconnect between these parameters and the rate of obesity. For example, obesity rate in some of well-industrialized countries with high literacy rates and food security is much greater than that in unfortunate countries. One may argue that availability of food may lead to high calorie intake, or high income may lead to less physical activities, and altogether these behaviors lead to overweight and obesity. If this is correct, then the low rates of obesity in less fortunate countries cannot be justified.

\section{What to blame}

One of the original theories of development of overweight and obesity is excess energy intake in the face of reduced energy expenditure [21]. This theory still maintains high acceptability world-wide. However, recent studies started to highlight quality of diets rather than the amount of dietary energy intake. Quality of daily diets can significantly vary among different populations. 


\section{Current Research in Diabetes \& Obesity Journal}

Similarly, the levels of regular physical activities significantly vary among various nations. Particularly, in the Western societies it is believed that screen time has significantly increased in recent years. While in some other less fortunate populations other factors may contribute to reduced levels of regular physical activities. Regardless, a combination of poor dietary habits and low physical activities are still the prime suspect of ever increasing rates of obesity world-wide. However, current international data may suggest contribution of other factors as well [24-26]. It seems reasonable to think that in addition to genetic factors some other biological, environmental and psychological factors play a crucial role in the global epidemic of obesity.

Table 1: The prevalence of obesity in select countries with different political, economic, educational, and natural resources.

\begin{tabular}{|c|c|c|c|c|c|c|c|c|c|c|}
\hline \multirow[t]{2}{*}{ Country } & \multirow{2}{*}{$\begin{array}{c}\text { Estimated } \\
\text { Current } \\
\text { Population } \\
\text { (Millions) } \\
\text { [33] }\end{array}$} & \multirow{2}{*}{$\begin{array}{c}\text { Reported } \\
\text { Adult Obesity } \\
\text { Rate (\%) [33] }\end{array}$} & \multirow{2}{*}{$\begin{array}{l}\text { GDP per } \\
\text { Person } \\
\text { (\$U.S., } \\
\text { Purchasing } \\
\text { Power } \\
\text { Parity, } \\
\text { 2017) [34] }\end{array}$} & \multirow{2}{*}{$\begin{array}{c}\text { Income } \\
\text { Inequality } \\
\text { (Gini } \\
\text { Coefficient) } \\
\text { [35-37] }\end{array}$} & \multirow{2}{*}{$\begin{array}{l}\text { Literacy Skills } \\
\text { of } 15 \text {-Year Olds } \\
(2015)[38,39]\end{array}$} & \multicolumn{2}{|c|}{ Political Features } & \multirow{2}{*}{$\begin{array}{c}\text { Natural } \\
\text { Resource } \\
\text { Rents as } \\
\text { Percent of } \\
\text { GDP (\%) } \\
(2015) \\
{[43,44]}\end{array}$} & \multirow{2}{*}{$\begin{array}{c}\text { Estimated } \\
\text { Food } \\
\text { Security } \\
\text { Index }(2017) \\
{[45,46]}\end{array}$} & \multirow{2}{*}{$\begin{array}{c}\text { Access to } \\
\text { Health } \\
\text { Care Index } \\
\text { (2015) } \\
{[47]}\end{array}$} \\
\hline & & & & & & $\begin{array}{l}\text { Free Press Index } \\
(2017)[40,41]\end{array}$ & $\begin{array}{l}\text { Democracy } \\
\text { Index } \\
(2017)[42]\end{array}$ & & & \\
\hline Algeria & 41.3 & 24.8 & 4,250 & $0.28(2011)$ & Below Average & 42.83 & Authoritarian & 12.0 & 51.5 & 64 \\
\hline Australia & 24.5 & 28.6 & 58,940 & $\begin{array}{c}34.70 \\
(2010)\end{array}$ & Above average & 16.02 & $\begin{array}{c}\text { Full } \\
\text { democracy }\end{array}$ & 4.8 & 83.3 & 90 \\
\hline Austria & 8.7 & 18.4 & 49,800 & $0.28(2015)$ & Average & 13.47 & $\begin{array}{c}\text { Full } \\
\text { democracy }\end{array}$ & 0.1 & 81.6 & 88 \\
\hline Brazil & 209.3 & 20.0 & 10,510 & $51.3(2015)$ & Below Average & 33.58 & $\begin{array}{c}\text { Flawed } \\
\text { democracy }\end{array}$ & 2.9 & 67.7 & 65 \\
\hline Canada & 35 & 28.0 & 44,770 & $0.32(2015)$ & Above average & 16.53 & $\begin{array}{c}\text { Full } \\
\text { democracy }\end{array}$ & 0.9 & 82.2 & 88 \\
\hline China & 1,409 & 6.9 & 9,380 & $42.2(2012)$ & Average & 77.66 & Authoritarian & 1.3 & 63.7 & 74 \\
\hline Ethiopia & 105 & 4 & 861 & $0.33(2010)$ & $\begin{array}{c}\text { Below average } \\
{[39]}\end{array}$ & 47.23 & Authoritarian & 14.3 & 33.3 & 44 \\
\hline Finland & 5.5 & 20.6 & 49,210 & $0.26(2015)$ & Above Average & 8.92 & $\begin{array}{c}\text { Full } \\
\text { democracy }\end{array}$ & 0.6 & 81.0 & 90 \\
\hline Indonesia & 264 & 5.7 & 4,120 & 39.5 (2013) & $\begin{array}{c}\text { Above average } \\
{[39]}\end{array}$ & 39.93 & $\begin{array}{c}\text { Flawed } \\
\text { democracy }\end{array}$ & 2.3 & 51.3 & 49 \\
\hline Italy & 59.3 & 21.0 & 33,730 & 34.7 (2014) & Average & 26.26 & $\begin{array}{c}\text { Flawed } \\
\text { democracy }\end{array}$ & 0.1 & 75.9 & 89 \\
\hline Japan & 127 & 3.3 & 38,550 & $0.33(2012)$ & Above average & 29.44 & $\begin{array}{c}\text { Flawed } \\
\text { democracy }\end{array}$ & 0.0 & 79.5 & 89 \\
\hline Jordan & 9.7 & 30.5 & 5,840 & 35.4 (2013) & Below Average & 43.24 & Authoritarian & 1.2 & 58.3 & 76 \\
\hline Korea & 50.9 & 5.8 & 30,920 & $0.29(2015)$ & Above Average & 27.61 & $\begin{array}{c}\text { Flawed } \\
\text { democracy }\end{array}$ & 0.0 & 74.7 & 86 \\
\hline Mexico & 129.2 & 28.1 & 10,020 & 48.2 (2014) & Below Average & 48.97 & $\begin{array}{c}\text { Flawed } \\
\text { democracy }\end{array}$ & 2.3 & 65.8 & 63 \\
\hline Norway & 5.3 & 23.10 & 75,340 & 0.27 (2015) & Above Average & 7.60 & $\begin{array}{c}\text { Full } \\
\text { democracy }\end{array}$ & 5.4 & 81.4 & 90 \\
\hline $\begin{array}{l}\text { Saudi } \\
\text { Arabia }\end{array}$ & 33 & 34.7 & 21,450 & 45.9 (2013) & $\begin{array}{c}\text { Above average } \\
{[39]}\end{array}$ & 66.02 & Authoritarian & 23.4 & 71.0 & 79 \\
\hline Sudan & 40 & 7.5 & 2,920 & 0.35 (2009) & Average [39] & 73.56 & Authoritarian & 4.2 & 34.8 & 50 \\
\hline Thailand & 69 & 8.5 & 6,740 & 39.4 (2013) & Below Average & 44.69 & $\begin{array}{l}\text { Hybrid } \\
\text { regime }\end{array}$ & 1.2 & 58.8 & 71 \\
\hline Turkey & 80 & 29.5 & 10,430 & $0.4(2014)$ & Below average & 49.46 & $\begin{array}{l}\text { Hybrid } \\
\text { regime }\end{array}$ & 0.4 & 61.1 & 76 \\
\hline UK & 66.2 & 28.1 & 40,030 & $0.36(2015)$ & Average & 22.26 & $\begin{array}{c}\text { Full } \\
\text { democracy }\end{array}$ & 0.3 & 84.6 & 85 \\
\hline USA & 325 & 33.0 & 59,500 & $0.39(2015)$ & Average & 23.27 & $\begin{array}{c}\text { Flawed } \\
\text { democracy }\end{array}$ & 0.3 & 84.6 & 81 \\
\hline
\end{tabular}




\section{Closing remarks}

Obesity and its comorbidities are now negatively affecting every single nation world-wide to a various extent [27-30]. Obesity can threat the mankind in many ways including productivity, fertility, physical and psychological disabilities, and consuming a significant portion of health care budget and facilities [31]. Although, recommendations for reduced fat intake seem to paradoxically be associated with an increase in obesity rate in general population, currently the best recommendation to battle this global health concern seems to be improvements in lifestyle including high quality diets and appropriate levels of regular physical activities [32]; reductions of non-dietary calorie sources such as alcohol not only help with the equation of calorie intake calorie expenditure, but also helps significantly with development of other disorders directly and/or indirectly associated with obesity and its comorbidities. In the meantime, detailed and focused investigations of other possible risk factors for obesity should be included in the priority list of scientists, physicians and other health care professionals as well as policy makers. This is an international mankind problem, and therefore begs international attention for developing effective strategies and polices to battle this worst enemy of wellbeing [33-47].

\section{Acknowledgement}

MHM's research program is supported by Natural Sciences and Engineering Research Council of Canada (NSERC). The authors would like to thank the St. Boniface Hospital Research Foundation for providing the infrastructure that enabled this study.

\section{References}

1. Chaturvedi P (2012) Antidiabetic potentials of momordica charantia: Multiple mechanisms behind the effects. J Med Food 15(2): 101-107.

2. Lee SY, Eom SH, Kim YK, Park NI, Park SU (2009) Cucurbitane-type triterpenoids in momordica charantia Linn. J Med Plant Res 3(13): 1264-1269.

3. Hazarika R, Parida P, Neog B, Yadav RNS (2012) Binding energy calculation of GSK-3 protein of human against some anti-diabetic compounds of momordica charantia L (Bitter melon). Bioinformation 8(6): 251-254.

4. Elliot M, Chithan K, Theoharis CT (2000) The effects of plant flavanoids on mammalian cells: Implications for inflammation, heart disease and cancer. Pharmacological Reviews 52(4): 673-751.

5. Glauce SB, Ana Carolina CM, Ana Michelle RL, Kalyne AM, Tiago GV (2004) Hypoglycemic and anti-lipemic effects of the aqueous extract from cissus sicyoides. Biomedical Central Pharmacology 4: 9-12.

6. Sui DY, Lu ZZ, Li SH, Cai Y (1994) Hypoglycemic effect of saponin isolated from leaves of acanthopanax senticosus (Rupr. Et Maxin) Harms. Chung Kuo Chung Yao Tsa Chih 19: 683-685.

7. Broadhurst CL, Polansky MM, Anderson RA (2000) Insulin like biological activity of culinary and medicinal plant aqueous extracts in vitro. Journal of Agriculture and Food Chemistry 48(3): 849-852.

8. Morton J (1987) Fruits of warm climates. Julia Morton Winterville North Carolina, Miami, USA.

9. Paramaguru R, Mazumder PM, Sasmal D (2014) Antidiabetic activity of pterospermum acerifolium flowers and glucose uptake potential of bioactive fraction in L6 muscle cell lines with Its HPLC fingerprint Bio Med Resear Internat 2014: 1-10.

10. Peng CH, Ker YB, Weng CF, Peng CC, Huang CN, et al. (2009) Insulin secretagogue bioactivity of finger citron fruit (Citrus medica L. var. Sarcodactylis Hort, Rutaceae). J Agric Food Chem 57(19): 8812-8819.

11. Ashok S, Ashish S, Tara C, Manoj K, Kailash (2013) Antidiabetic and antihyperlipidemic activity of cucurbitamaxima duchense (Pumpkin) seeds on streptozotocin induced diabetic rats. Journal of Pharmacognosy and Phytochemistry 1: 108.

12. Budhiraja RD, Sudhir S, Garga KN (1977) Pharmacological investigations on fruits of withania coagulans, dunal. Planta Med 32(2): 154-157.

\section{Your next submission with Juniper Publishers will reach you the below assets}

- Quality Editorial service

- Swift Peer Review

- Reprints availability

- E-prints Service

- Manuscript Podcast for convenient understanding

- Global attainment for your research

- Manuscript accessibility in different formats

( Pdf, E-pub, Full Text, Audio)

- Unceasing customer service

Track the below URL for one-step submission https://juniperpublishers.com/online-submission.php 